\title{
High Lift Common Research Model for Wind Tunnel Testing: An Active Flow Control Perspective
}

\author{
John C. Lin ${ }^{*}$, Latunia P. Melton ${ }^{\dagger}$, Sally A. Viken ${ }^{*}$, Marlyn Y. Andino ${ }^{\S}$, \\ Mehti Koklu $^{* *}$, Judith A. Hannon ${ }^{\dagger \dagger}$, and Veer N. Vatsa \\ NASA Langley Research Center, Hampton, VA, 23681, USA
}

\begin{abstract}
This paper provides an overview of a research and development effort sponsored by the NASA Advanced Air Transport Technology Project to achieve the required high-lift performance using active flow control (AFC) on simple hinged flaps while reducing the cruise drag associated with the external mechanisms on slotted flaps of a generic modern transport aircraft. The removal of the external fairings for the Fowler flap mechanism could help to reduce drag by 3.3 counts. The main challenge is to develop an AFC system that can provide the necessary lift recovery on a simple hinged flap high-lift system while using the limited pneumatic power available on the aircraft. Innovative low-power AFC concepts will be investigated in the flap shoulder region. The AFC concepts being explored include steady blowing and unsteady blowing operating in the spatial and/or temporal domain. Both conventional and AFC-enabled high-lift configurations were designed for the current effort. The high-lift configurations share the cruise geometry that is based on the NASA Common Research Model, and therefore, are also open geometries. A 10\%-scale High Lift Common Research Model (HL-CRM) is being designed for testing at the NASA Langley Research Center 14- by 22-Foot Subsonic Tunnel during fiscal year 2018. The overall project plan, status, HL-CRM configurations, and AFC objectives for the wind tunnel test are described.
\end{abstract}

\section{Nomenclature}

\begin{tabular}{|c|c|c|}
\hline $\mathrm{C}_{\mathrm{L}}$ & $=$ & lift coefficient \\
\hline $\mathrm{C}_{\mathrm{ref}}$ & $=$ & $\begin{array}{l}\text { wing reference chord; } \mathrm{C}_{\text {ref }}=\text { local wing chord for the slat and outboard flap, and } \\
\mathrm{C}_{\text {ref }}=\text { wing chord at the yehudi break for the inboard flap }\end{array}$ \\
\hline $\mathrm{C}_{\mu}$ & $=$ & momentum coefficient \\
\hline $\mathrm{L} / \mathrm{D}$ & $=$ & lift to drag ratio \\
\hline $\mathrm{M}_{\infty}$ & $=$ & freestream Mach number \\
\hline $\mathrm{Re}, \mathrm{RN}$ & $=$ & Reynolds number \\
\hline $\mathrm{x}, \mathrm{y}, \mathrm{z}$ & $=$ & $\begin{array}{l}\text { coordinates along the longitudinal axis, lateral axis, and normal axis, } \\
\text { respectively, of the HL-CRM }\end{array}$ \\
\hline$\Delta \mathrm{C}_{\mathrm{L}}$ & $=$ & lift coefficient increment \\
\hline $14 \times 22$ & $=$ & NASA Langley Research Center 14- by 22-Foot Subsonic Tunnel \\
\hline AATT & $=$ & Advanced Air Transport Technology \\
\hline AFC & $=$ & active flow control \\
\hline
\end{tabular}

* Senior Research Scientist, Flow Physics and Control Branch, MS 170, AIAA Associate Fellow

+ Senior Research Scientist, Flow Physics and Control Branch, MS 170, AIAA Associate Fellow

\$ Senior Research Scientist, Configuration Aerodynamics Branch, MS 499, AIAA Senior Member

$\S$ Research Scientist, Flow Physics and Control Branch, MS 170, AIAA Senior Member

** Research Scientist, Flow Physics and Control Branch, MS 170

${ }^{\dagger}$ Research Scientist, Flow Physics and Control Branch, MS 170

$¥$ Senior Research Scientist, Computation AeroSciences Branch, MS 128, AIAA Associate Fellow 


$\begin{array}{ll}\text { APU } & =\text { auxiliary power unit } \\ \text { CAD } & =\text { computer-aided design } \\ \text { CFD } & =\text { computational fluid dynamics } \\ \text { CRM } & =\text { electronically scanned pressure } \\ \text { ESP } & =\text { fiscal year } \\ \text { FY } & =\text { High Lift Common Research Model } \\ \text { HL-CRM } & =\text { infrared } \\ \text { IR } & =\text { Langley Research Center } \\ \text { LaRC } & =\text { Particle Image Velocimetry } \\ \text { MAC } & =\text { slat-cove filler } \\ \text { PIV } & =\text { slat-gap filler } \\ \text { SCF } & =\text { Subsonic Transport Aeroacoustic Research } \\ \text { SGF } & =\text { Trapezoidal Wing } \\ \text { STAR } & =\text { wing under slat surface } \\ \text { STEP } & \text { Trap Wing }\end{array}$

\section{Introduction}

$\mathrm{T}$

HE sizing, economics, and safety of modern transport aircraft are strongly influenced by their high-lift systems. ${ }^{1}$ The NASA Advanced Air Transport Technology (AATT) Project is seeking to demonstrate the potential benefits of reducing the cruise drag associated with modern high-lift systems without sacrificing aerodynamic and acoustic performance during takeoff and landing operations. One possible approach is to use active flow control (AFC) $)^{2,3}$ to provide the required lift performance while reducing the cruise drag associated with the external mechanisms used to deploy a slotted flap during high-lift operations. ${ }^{4,5}$ NASA is seeking to perform wind tunnel testing of AFC-enabled high-lift systems within the framework of the AATT Project goals to reduce fuel burn and noise of modern civil transport aircraft.

A recent system integration study indicated that up to a $2.25 \%$ fuel burn reduction is possible if an AFC-enabled simplified high lift system (i.e., simple hinged flaps inboard and outboard) could provide the necessary lift recovery at the approach angle of attack. ${ }^{5}$ The AFC-related performance gains are primarily due to the 3.3-count excrescence drag reduction from the removal of the external fairings for the Fowler flap mechanism (see Fig. 1(a) for a typical example $^{6}$ ). However, the main challenge here is to develop an AFC system that can provide the necessary lift recovery for a simple hinged flap high-lift system (Fig. 1(b)) while using the limited pneumatic power available on the aircraft. Innovative low-power AFC concepts, such as the traverse actuator ${ }^{7-9}$ and fluidic oscillators, ${ }^{10,11}$ will be investigated around the flap shoulder region. The AFC concepts include steady and unsteady blowing that operate in the spatial and/or temporal domains. The AFC concepts for drag reduction will also leverage the knowledge gained from the existing AFC-enhanced vertical tail test dataset, comprised of subscale ${ }^{12,13}$ and full-scale ${ }^{14,15}$ wind tunnel test data, and flight demonstration data ${ }^{16}$ which were the culmination of several years of research and development. ${ }^{17}$

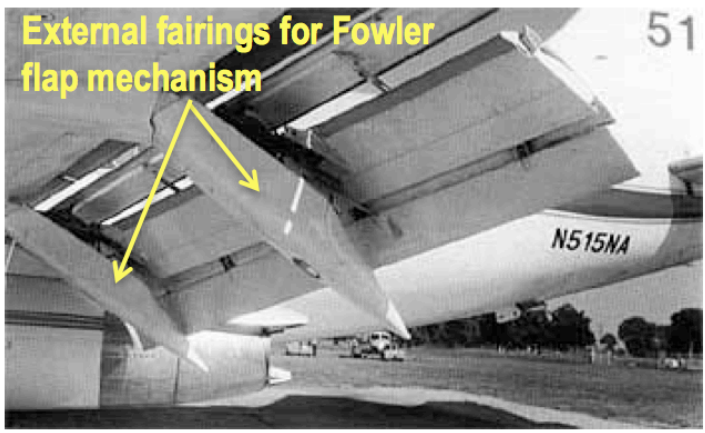

(a) An example of external fairings for Fowler flap mechanism. ${ }^{6}$

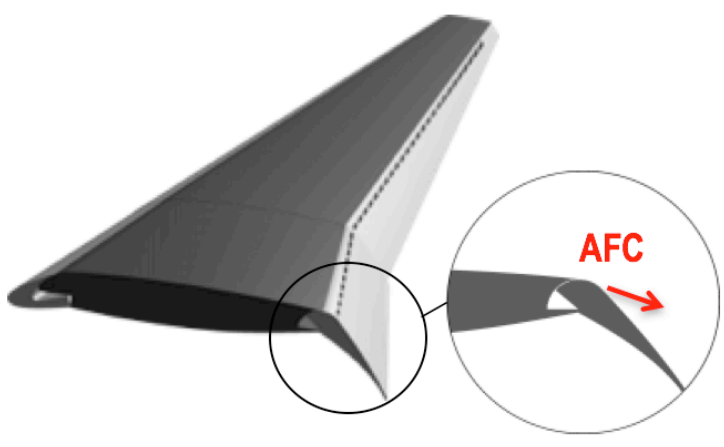

(b) A simple hinged flap high-lift wing with AFC (no external fairings).

Figure 1. Concept of AFC-enabled high-lift system for drag reduction. 
Although the initial motivation to develop an "open" high-lift geometry was for AFC research, there are also strong desires for such a geometry from government, industry, and academia for R\&D efforts related to noise reduction, high-lift aerodynamics/flow physics, and CFD development/validation. For example, the Trapezoidal Wing (Trap Wing) mode ${ }^{18,19}$ and the Subsonic Transport Aeroacoustic Research (STAR) mode ${ }^{20,21}$ were developed to provide semispan high-lift testing data for aerodynamic and aeroacoustic research. However, the Trap Wing is a generic high-lift geometry that lacks the high-fidelity details typical of a transport aircraft, and the aerodynamic data of the STAR model are considered proprietary. ${ }^{21}$ Consequently, a new open high-lift geometry representative of a modern transport aircraft (i.e., containing relevant flow physics, aerodynamic, and aeroacoustic features) is highly desirable.

The current high-lift research effort involves both conventional (baseline) and AFC-enabled high-lift configurations that are based on the NASA Common Research Model (CRM) ${ }^{22,23}$ A $10 \%$-scale high-lift model is being designed for wind tunnel testing during fiscal year (FY) 2018. This paper will describe the high-lift configurations and the AFC concepts currently under development for the wind tunnel test, as well as the project plan, schedule, and model design features and status.

\section{HL-CRM Geometry}

\section{Conventional High-Lift Configuration (Baseline)}

The high-lift configuration, as reported by Lacy and Sclafani, ${ }^{24}$ shares the CRM cruise geometry. Likewise, the current high-lift geometry is intended to be open as well. Because the original CRM cruise geometry was designed for transonic speeds, a minor modification on the leading edge was needed to resolve high-lift aerodynamic issues at low speeds. Figure 2 illustrates the modification for the HL-CRM configuration, as the effective leading-edge radius was increased to resolve a stall issue. In addition, a one-piece wing loft was created for easier CFD implementation.

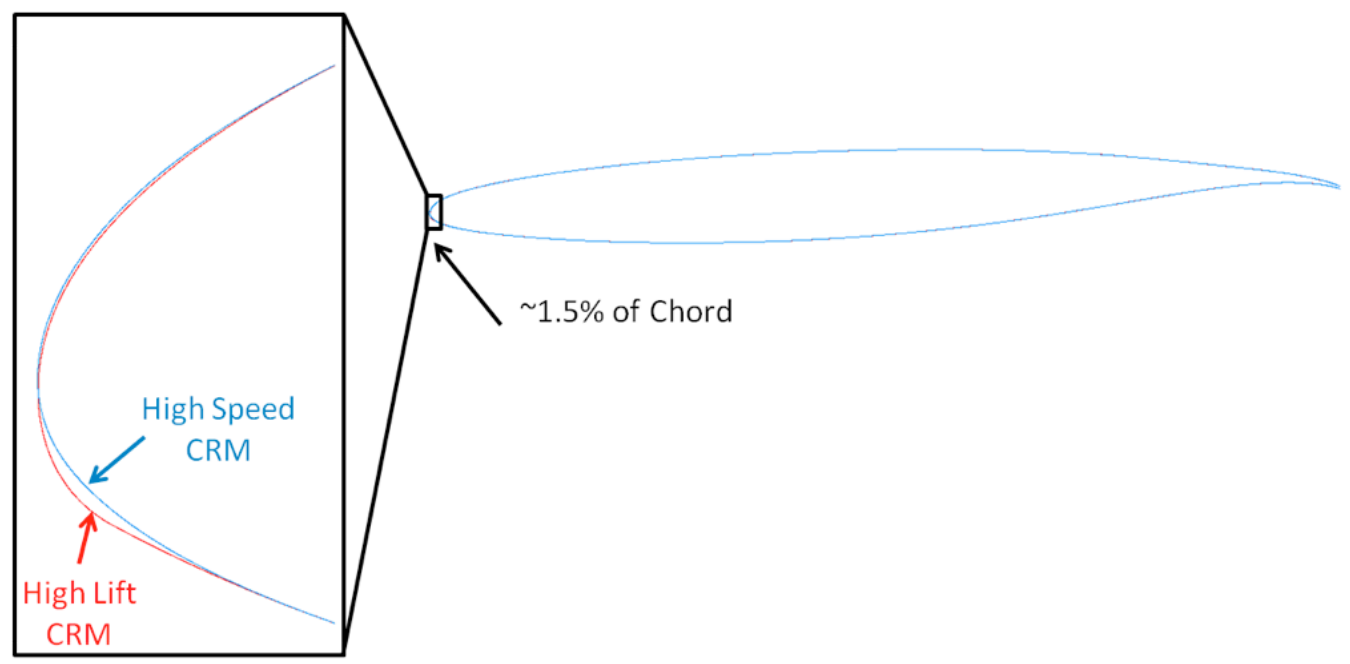

Figure 2. Leading edge modification of HL-CRM configuration (Lacy \& Sclafani ${ }^{24}$ ).

The conventional high-lift configuration, as predicted by OVERFLOW and CFD++, is expected to have a maximum lift coefficient of around 2.3 to 2.4 for landing and 2.0 to 2.1 for takeoff ${ }^{24}$ at $\mathrm{Re}=24.6$ million and $\mathrm{M}_{\infty}=$ 0.2 (see Fig. 3). From the AFC perspective, the conventional high-lift configuration serves as the baseline that the AFC-enabled high lift configuration (see next Section) seeks to match. For example, at the landing approach angle of attack (AOA) of $8^{\circ}$, the lift coefficient of the former is approximately 1.8, which is the lift value that the latter needs to recover.

Currently, CAD files of a simpler version of the CRM high-lift geometry (without the engine nacelle, landing gear, slat and flap supporting brackets, and horizontal tail, etc.) are on the NASA website. ${ }^{25}$ This geometry will also be used for the Geometry and Mesh Generation Workshop-1 (GMGW-1) at the AIAA AVIATION 2017 Forum. 
Tail-Off Lift Comparison

$\mathrm{RN}=24.6$ million, Mach $=0.2$

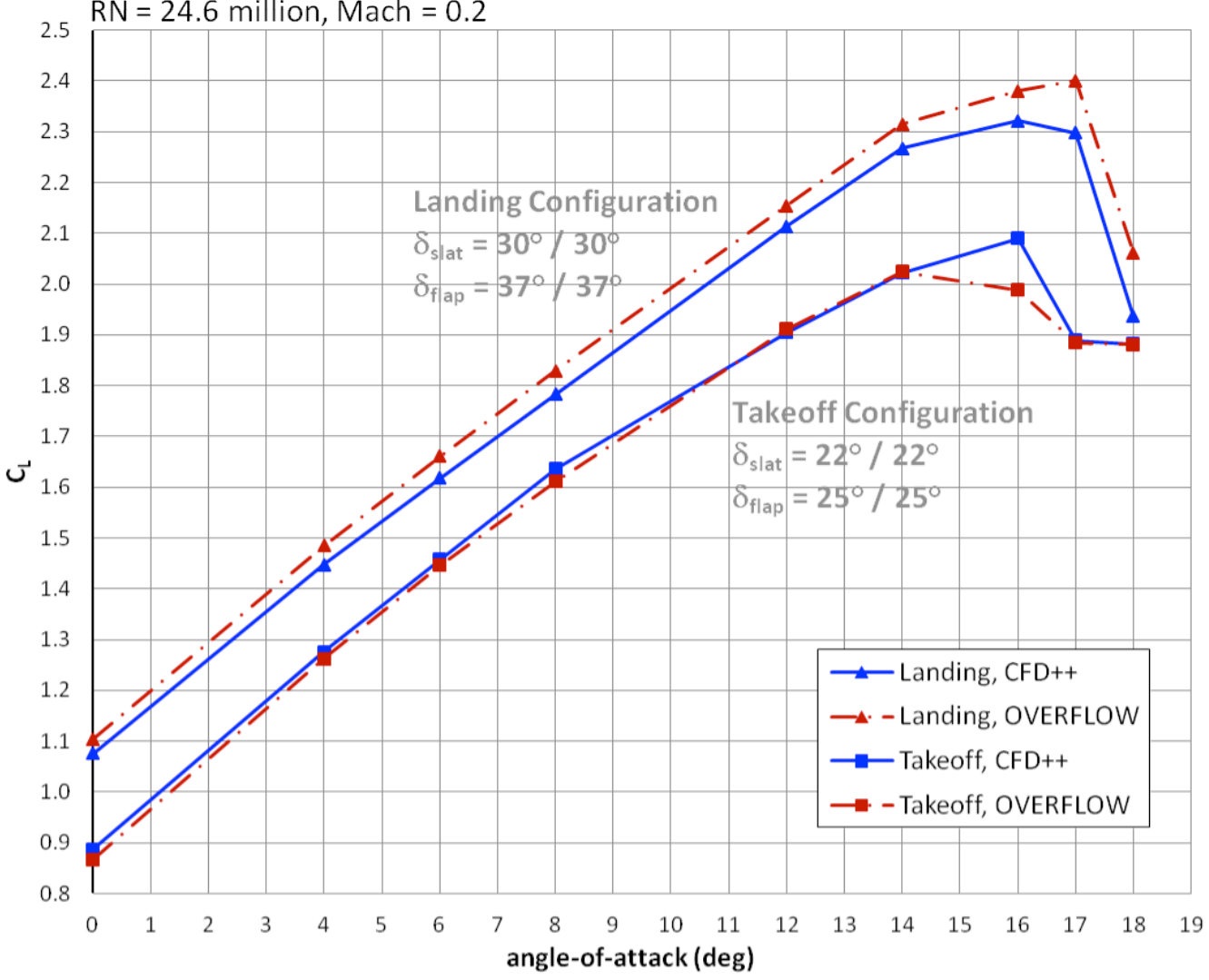

Figure 3. Lift performance of conventional HL-CRM configuration (Lacy \& Sclafani ${ }^{24}$ ).

\section{AFC-Enabled High-Lift Configuration}

A simple hinged flap high-lift configuration will be used for AFC implementation. The slat and forward portion of the main wing (i.e., less than approximately $70 \%$ of cruise chord) of the AFC-enabled high-lift configuration is the same as that of the conventional high-lift geometry. The initial AFC focus is to achieve the necessary lift recovery at an approach angle of attack (i.e., $\sim 8^{\circ}$ ) for a simple hinged flap high-lift system while using the available pneumatic power on the aircraft during landing when the engine is at idle power. By keeping the conventional slat, the expectation is that the maximum lift should not change significantly.

\section{AFC Challenges}

The current effort on the AFC-enabled high-lift wing leverages the knowledge gained from the recent successful demonstration of the AFC-enhanced vertical tail technology. ${ }^{12-17}$ The AFC-enabled high-lift wing in the landing configuration encounters a more difficult lift recovery challenge ${ }^{5}$ than the AFC-enhanced vertical tail application, as summarized in Table 1. Because the lifting surface is smaller due to the elimination of the Fowlerflap system, the lift coefficient increase $\left(\Delta \mathrm{C}_{\mathrm{L}}\right)$ for the AFC-enabled high-lift system is about twice that required for the AFC-enabled vertical tail - i.e., $\Delta \mathrm{C}_{\mathrm{L}}=0.44$ lift increase versus equivalent $\Delta \mathrm{C}_{\mathrm{L}} \sim 0.2$ (side force enhancement for the latter).

High-lift wings also generate higher adverse pressure gradients compared to the vertical tail because of higher maximum flap deflections (i.e., $\geq 50^{\circ}$ instead of $30^{\circ}$ ) and higher AOA (i.e., $8^{\circ}$ and $16^{\circ}$ instead of $0^{\circ}$ and $7.5^{\circ}$ ) for aerodynamic optimization. The higher freestream speed required for the high-lift application $-\mathrm{M}_{\infty}=0.2(\sim 130$ knots) versus of $M_{\infty}=0.15(\sim 100$ knots $)$ - also reduces the effective momentum coefficient $\left(C_{\mu}\right)$ at the same pneumatic power setting. In addition, the engine is at idling power during landing, therefore, the bleed air for highlift wings is limited. The available mass flow and pressure are moderately less than what the auxiliary power unit (APU) was able to provide for the AFC-enhanced vertical tail implementation. In summary, for the landing configuration, the AFC-enabled high-lift wing is required to achieve more lift with less pneumatic power when compared to the AFC-enhanced vertical tail. 
Table 1. Challenges of an AFC-enabled high-lift system as compared to an AFC-enhanced vertical tail.

\begin{tabular}{|c|c|c|c|}
\hline & $\begin{array}{l}\text { AFC-Enhanced } \\
\text { Vertical Tail }^{12-17}\end{array}$ & $\begin{array}{c}\text { AFC-Enabled } \\
\text { Simple Hinged Flap } \\
\text { High Lift Wing }^{5}\end{array}$ & $\begin{array}{c}\text { Increased Challenges for } \\
\text { Simple Hinged Flap High Lift } \\
\text { Wing }\end{array}$ \\
\hline $\begin{array}{l}\text { Lift Increments } \\
\qquad\left(\Delta \mathbf{C}_{\mathrm{L}}\right)\end{array}$ & $\sim 0.2$ & 0.44 & $\begin{array}{c}\text { Smaller lifting surface due to } \\
\text { elimination of Fowler flap } \\
\text { system }\end{array}$ \\
\hline $\begin{array}{l}\text { Maximum Flap } \\
\text { Deflection }\end{array}$ & $30^{\circ}$ & $\geq 50^{\circ}$ & $\begin{array}{c}\text { Increased adverse pressure } \\
\text { gradient }\end{array}$ \\
\hline $\begin{array}{c}\text { AOA for } \\
\text { Aerodynamic } \\
\text { Optimization }\end{array}$ & $0^{\circ}$ and $7.5^{\circ}$ & $\begin{array}{l}8^{\circ} \text { (approach) and } 16^{\circ} \\
\text { (maximum lift) }\end{array}$ & $\begin{array}{c}\text { Increased adverse pressure } \\
\text { gradient }\end{array}$ \\
\hline $\begin{array}{l}\text { Freestream Speed } \\
\text { for AFC Design }\end{array}$ & $\mathrm{M}=0.15(\sim 100$ knots $)$ & $\mathrm{M}=0.2(\sim 130$ knots $)$ & Effective $C_{\mu}$ is reduced \\
\hline $\begin{array}{l}\text { Pneumatic power } \\
\text { available }\end{array}$ & APU on during takeoff & $\begin{array}{l}\text { Engine air bleed at idle } \\
\text { power during landing }\end{array}$ & $\begin{array}{c}\text { Available mass flow and } \\
\text { pressure are reduced }\end{array}$ \\
\hline
\end{tabular}

A recent CFD study has shown that traverse actuation can achieve $\sim 0.2 \Delta \mathrm{C}_{\mathrm{L}}$ on an AFC-enabled high-lift system with the available pneumatic power, but an additional $\sim 0.24 \Delta \mathrm{C}_{\mathrm{L}}$ lift enhancement is still required. ${ }^{5}$ The traverse actuation system employs a small and fast moving jet packet that travels periodically in the spanwise direction toward the fuselage. Traverse actuation at $10 \mathrm{~Hz}$ applied only on the inboard flap could reduce the mass flow rate requirements by about an order of magnitude compared to nontraverse (steady) blowing, while still being able to reduce separated flow over both the inboard and outboard trailing-edge flaps. ${ }^{5}$

The current AFC-enabled high lift configuration will have a simple hinged flap with AFC on the flap shoulder for lift recovery on the landing configuration as described above. The model design will also have provisions for some localized AFC concepts aimed at increasing the lift to drag ratio (L/D) for the takeoff configuration. Garner et al. ${ }^{26}$ indicated that a $1 \%$ increase in $\mathrm{L} / \mathrm{D}$ for takeoff is equivalent to 2800 pounds increase in payload or 150 nautical miles increase in range. From the fuel burn savings perspective, the L/D improvement for takeoff could lead to a transport aircraft with smaller engines that use less fuel.

\section{$\underline{\text { AFC Strategies }}$}

The strategies for AFC-enabled lift recovery are to perform parallel investigations both experimentally and computationally for risk reduction purposes. Experimentally, there are ongoing efforts to examine multiple rows of AFC actuation on the flap shoulder region of a geometry derived from the simple hinged flap HL-CRM design. There is some experimental evidence from the work of DeSalvo et al. ${ }^{27,28}$ suggesting that multiple rows of AFC actuation on a simple hinged flap high-lift airfoil could be effective at lift enhancement while keeping the momentum coefficient at relatively low levels.

The sweeping jet actuator design to be used for the current effort is similar to the Mod 2 geometry as reported by Melton et al. ${ }^{29}$ Using an array of high-speed valves, a functional traverse actuation method referred to as "Śpanwise Traversing Electro-Pneumatic (STEP) actuators" is also being developed at the NASA Langley Research Center (LaRC). AFC approaches using multiple rows of actuators and STEP actuators will be tested in low-speed wind tunnels at NASA LaRC prior to the NASA LaRC 14- by 22-Foot Subsonic Tunnel (14x22) test entry. Table 2 summarizes the planned AFC strategies for the HL-CRM testing at the $14 \times 22$. 
Table 2. Summary of AFC test plan for HL-CRM landing configuration at the $14 \times 22$.

\begin{tabular}{|c|c|c|c|}
\cline { 2 - 4 } \multicolumn{1}{c|}{} & Mass flow range & Pressure ratio range & AFC parameters \\
\hline $\begin{array}{c}\text { Simple hinged flap } \\
\text { baseline (AFC off) }\end{array}$ & N/A & N/A & N/A \\
\hline $\begin{array}{c}\text { Discrete nozzle } \\
\text { actuators }\end{array}$ & Up to $1 \mathrm{lb} / \mathrm{s}$ & 1 to 3 & $\begin{array}{c}\text { Multiple row actuation and } \\
\text { actuator spacing }\end{array}$ \\
\hline Sweeping jet actuators & Up to $1 \mathrm{lb} / \mathrm{s}$ & 1 to 3 & $\begin{array}{c}\text { Multiple row actuation and } \\
\text { actuator spacing }\end{array}$ \\
\hline $\begin{array}{c}\text { STEP actuators } \\
\text { (traverse actuation) }\end{array}$ & Up to $1 \mathrm{lb} / \mathrm{s}$ & 1 to 3 & $\begin{array}{c}\text { Traversing actuation } \\
\text { frequency and coverage }\end{array}$ \\
\hline $\begin{array}{c}\text { Steady slot blowing } \\
\text { (optional - depending } \\
\text { on manufacturability) }\end{array}$ & Up to $1 \mathrm{lb} / \mathrm{s}$ & & N/A \\
\hline
\end{tabular}

\section{Noise Measurement and Reduction}

High-lift components cause unsteady flow and acoustic noise due to high-speed flow through gaps and vortical flow from component edges. From the AFC perceptive, the simple hinged flap should reduce the noise associated with the flow through the flap gap; however, exiting jets from AFC actuators also introduce new sources of noise. Consequently, it is important to acquire acoustic data on an AFC-enabled high-lift system to determine whether there is a net increase or decrease in the noise levels. In addition, the acoustic portion of the HL-CRM test will demonstrate two new noise reduction concepts: (1) flexible slat-cove filler (SCF) ${ }^{30}$ and (2) slat-gap filler (SGF) ${ }^{31}$ for airframe noise treatments. The goal of these concepts is to reduce the slat noise without any penalty to aerodynamic performance. The primary objective of the aeroacoustic investigation is to test and compare the aerodynamic performance and noise characteristics of the baseline model and the models with rigid and flexible SCF and SGF treatments. The secondary objective is to test a selected group of flap-edge noise devices as reported by Khorrami et al. $^{32}$

\section{CFD Synergy}

There are parallel CFD efforts to explore the AFC design space at NASA LaRC (using the PowerFLOW $\operatorname{code}^{33,34}$ for AFC and FUN3D ${ }^{35}$ for the baseline cases) and Boeing (using OVERFLOW ${ }^{36-38}$ ). Parameters to be examined may include (but are not limited to) higher flap deflection $\left(\geq 50^{\circ}\right.$ ), flaps with longer chords, and various aforementioned low pneumatic power AFC concepts.

Once all the model details are finalized after the Critical Design Review at the end of March 2017, the final CAD files of the HL-CRM geometry for both the conventional and the AFC-enabled simple hinged flap cases (with the engine nacelle, landing gear, slat and flap supporting brackets, etc.) will be uploaded onto the NASA website. ${ }^{25}$ The geometry is to be used for the AIAA High-Lift Prediction Workshops as part of its long term goals for CFD development. $^{39,40}$

\section{Wind Tunnel Test}

The wind tunnel test will be performed at the NASA LaRC 14 - by 22 -Foot Subsonic Tunnel $(14 \times 22){ }^{41}$ as shown in Fig. 4. The $14 \times 22$ is an atmospheric, closed return wind tunnel with a test section 14.5-ft high, 21.75-ft wide, and 50-ft long, a maximum freestream velocity of $338 \mathrm{ft} / \mathrm{s}$, and a dynamic pressure (q) of $144 \mathrm{psf}$. The unit Reynolds number per foot ranges from 0 to $2.2 \times 10^{6}$. Test section airflow is driven by a 40-ft diameter, 9-bladed fan powered by a $12,000-\mathrm{hp}$ solid-state converter with synchronous motor. The tunnel has a set of flow control vanes to maintain control of the speed for low-speed testing.

A $10 \%$-scale semispan (right wing) HL-CRM will be designed and tested in the $14 \times 22$. The aerodynamic portion of the test will be performed with closed sidewalls (sidewalls down), while the aeroacoustic portion will be performed with opened sidewalls (sidewalls up). The top insert in Fig. 1 shows an example of the latter, ${ }^{32}$ and the bottom insert shows an example of the former. ${ }^{42}$ The landing configurations will be tested at $\mathrm{M}_{\infty}=0.2$, while takeoff configurations will be tested at $\mathrm{M}_{\infty}=0.26$. 


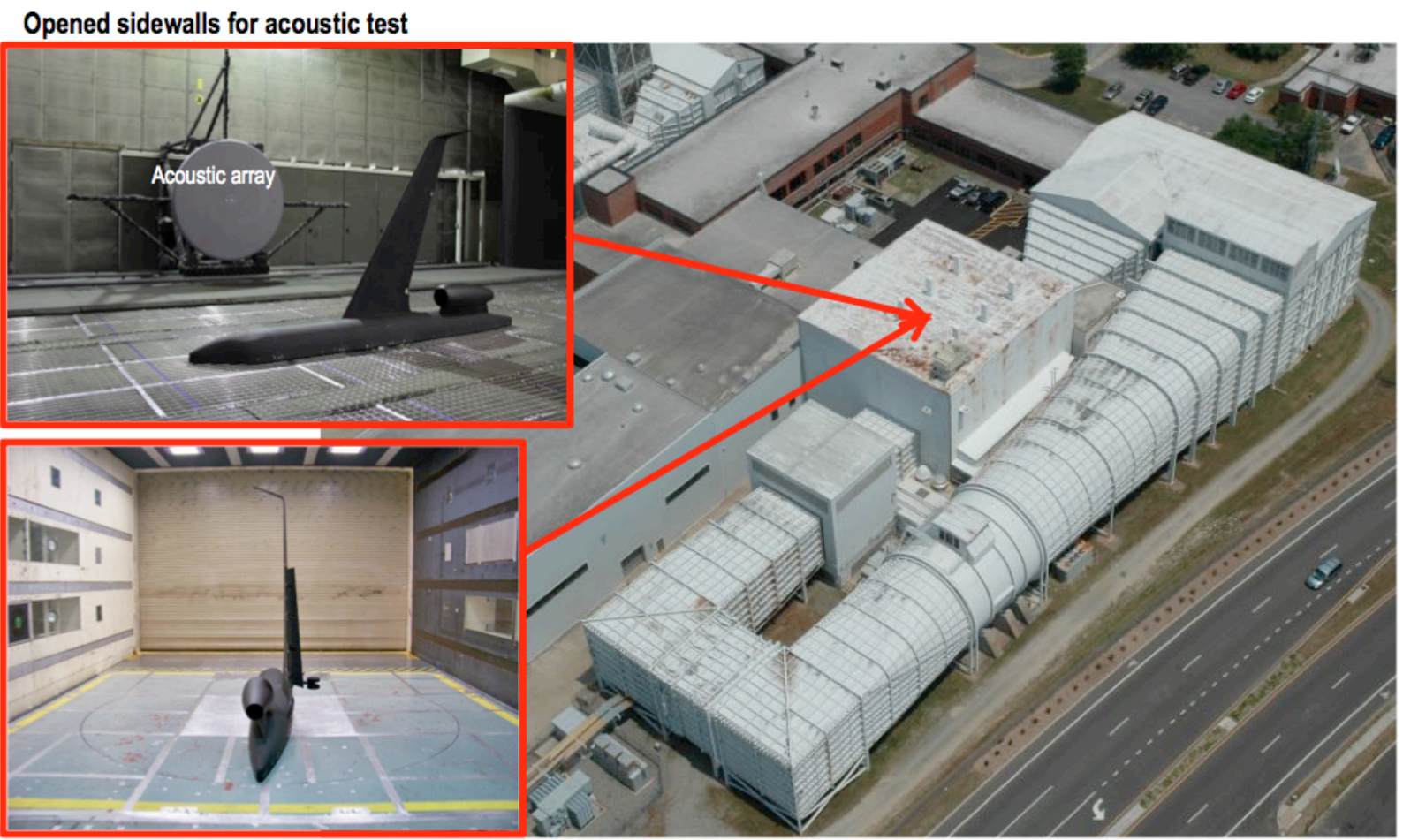

Closed sidewalls for aerodynamic test

Figure 4. NASA Langley 14- by 22-Foot Subsonic Tunnel. Top left insert is an example of open sidewalls for an aeroacoustic test. ${ }^{32}$ Bottom left insert is an example of closed sidewalls for an aerodynamic test. ${ }^{42}$

The planned experimental measurements include forces and moments using a balance (NASA MC-110), surface pressures using pressure taps and ESP modules (for steady) and Kulite ${ }^{\circledR}$ sensors (for unsteady), model deflection using videogrammetry, structure vibration using a laser vibrometer, airframe noise using acoustic arrays (in the acoustic portion of the test), and flow visualization using tufts and infrared (IR) cameras (for transition detection). If the schedule and resources allow, Particle Image Velocimetry (PIV) may be used to measure the off-body flow field.

\section{Model Design}

The main components of the half-body model are a semispan wing, a nacelle/pylon, and a semispan fuselage with a horizontal tail. The model will primarily be used to parametrically explore the effects of different AFC systems on a simple hinged flap high-lift configuration with a conventional slat. The model will also be used for CFD validation and aeroacoustic measurements. Depending on the achievable modularity of the HL-CRM design for the $14 \times 22$, it is conceivable that this model could be used for future generic testing of advanced/alternate AFC applications, flap/slat layouts, and aeroacoustic treatments.

Key model components such as slat, wing under slat surface (WUSS), spoiler, and flap are all modular and replaceable. The modular approach provides flexibility and enables the model to be switched between conventional and AFC-enabled simple hinged flap high-lift configurations. The center spar remains the same for both high-lift configurations. Provisions are also made for interchangeable model pieces for regions at the flap and slat side edges, wingtip, and aileron. The engine nacelle/pylon, and horizontal tail are removable on an as-needed basis.

A sketch of the HL-CRM in the $14 \times 22$ is shown in Fig. 5. The 10\%-scale semispan model is to be installed on top of a 0.29 foot ( $\sim 3.5$ inches) standoff (or peniche), and as a result, the model and its standoff will cover $68 \%$ of the tunnel span in the vertical direction. The model center will be located 0.54 feet ( 6.5 inches) downstream from the turntable center. The model fuselage is 20.59 feet in length; therefore, it extends past the turntable and past the end of the cart. 


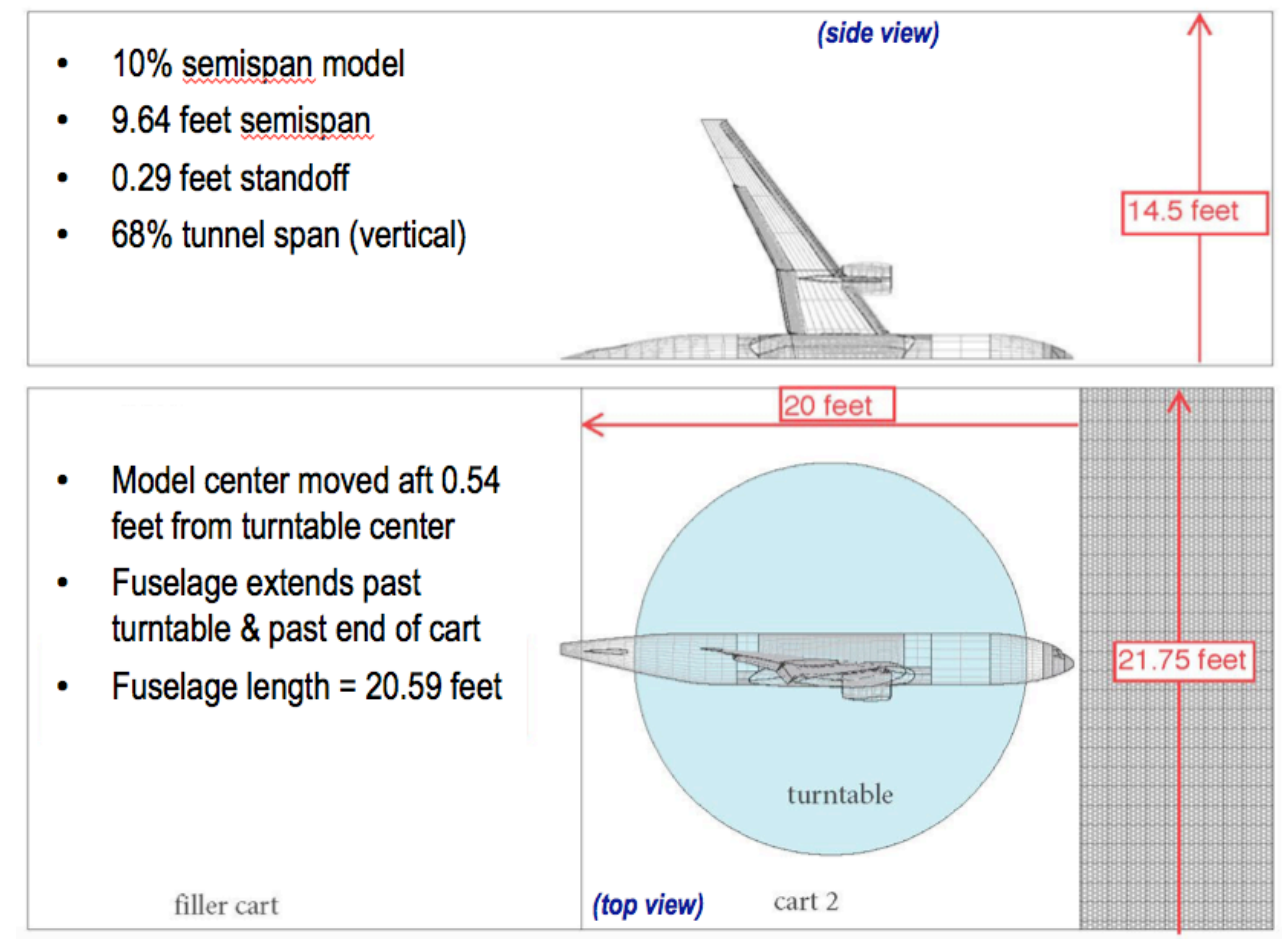

Figure 5. Semispan HL-CRM test in the $14 \times 22$.

Key model geometric reference parameters used for computing force and moment coefficients are:

- Mean aerodynamic chord $(\mathrm{MAC})=27.58$ inches

- Wing semispan $=115.675$ inches

- Reference (planform) area of the semispan model $=2,973.6 \mathrm{in}^{2}$

- Moment reference center (MRC): $x=132.59$ inches, $y=46.875$ inches, $z=17.795$ inches

- Based on MAC, $\mathrm{Re}=3.27 \times 10^{6}$ for $\mathrm{M}_{\infty}=0.20$ (landing configuration) and $\mathrm{Re}=4.24 \times 10^{6}$ for $\mathrm{M}_{\infty}=0.26$ (takeoff configuration)

The schematic of the approximate pressure tap locations, indicated by the red dotted lines, is shown in Fig. 6 . Most of the pressure taps are in the streamwise arrays at 8 spanwise locations with 3 rows across the inboard flap span, 3 rows across the outboard flap span, and 2 rows across the aileron region. Additionally, 6 spanwise arrays are on the upper wing surface with 1 row on the slat, 3 rows on the main wing, and 2 rows on the flap. The total number of pressure taps on the wing is approximately 680 . Other locations for pressure taps include the fuselage $(\sim 100)$, nacelle/pylon $(\sim 100)$, and horizontal stabilizer $(\sim 20)$. In total, there are approximately 900 pressure taps on the configuration. There will also be approximately 100 unsteady pressure sensors installed on the model. The design of the slat and flap brackets is ongoing. Once the bracket number and location are decided, the pressure tap locations and number will be further adjusted to avoid any bracket interference.

Table 3 summarizes the slat and flap riggings for the conventional and the simple hinged flap high-lift configurations at the MAC $(y=46.875$ inches $)$. For the conventional HL-CRM geometry, the nominal slat and flap deflections are $22^{\circ}$ and $25^{\circ}$, respectively, for the takeoff configuration, and $30^{\circ}$ and $37^{\circ}$, respectively, for the landing configuration. For the simple hinged flap HL-CRM geometry, the nominal slat and flap deflections are $30^{\circ}$ and $50^{\circ}$, respectively, for the landing configuration. The nominal flap and slat deflections are generally the same for both inboard and outboard slats and flaps. The engine nacelle location is the boundary for the inboard and outboard slats and the yehudi break is the boundary for the inboard and out board flaps. The gap and overhang definition is the same as that reported by Lin and Dominik ${ }^{43}$ (see Fig. 7). Notice that one should use local wing chord as the reference chord $\left(\mathrm{C}_{\mathrm{ref}}\right)$ for the slat and the outboard flap, and use wing chord at the yehudi break as $\mathrm{C}_{\text {ref }}$ for the inboard flap. Typically, the range of adjustability for the slat gap, slat overhang, and flap overhang is $\sim 3 \% \mathrm{C}_{\text {ref. }}$ The flap gap range of adjustability is $\sim 1.5 \% \mathrm{C}_{\text {ref }}$. The flap gap is fairly constant at $1.25 \% \mathrm{C}_{\text {ref }}$ and $0.9 \% \mathrm{C}_{\text {ref }}$ for the landing and takeoff configurations, respectively, across the model span, as reported by Lacy \& Sclafani. ${ }^{24}$ However, there is more variability for the flap overhang, slat gap, and slat overhang across the span. 


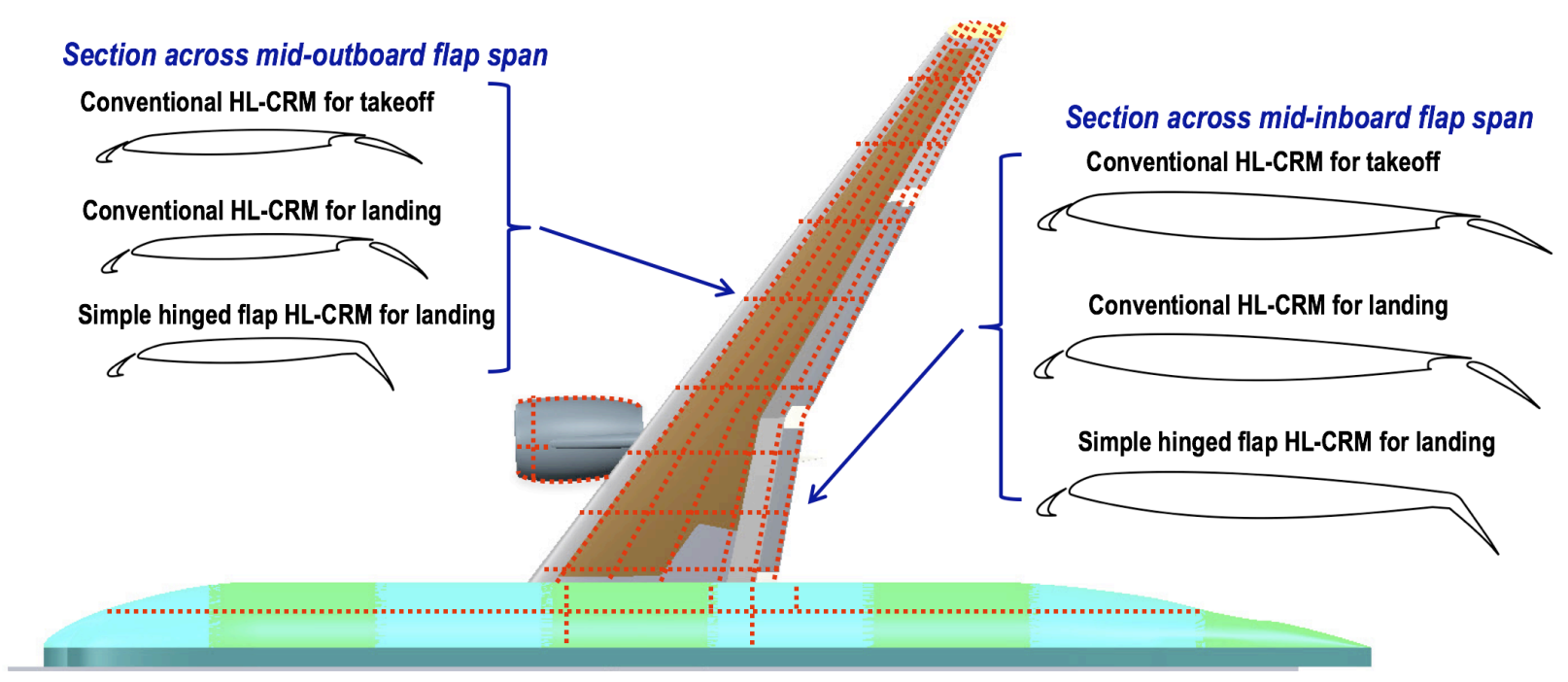

Figure 6. Schematic of pressure tap locations (as indicated by dotted red lines) and cross section of the representative high lift configurations.

Table 3. Slat and flap rigging for the HL-CRM configurations at MAC $(y=46.875$ inches $)$.

\begin{tabular}{|c|c|c|c|c|c|}
\hline \multirow{2}{*}{\multicolumn{2}{|c|}{ Configuration }} & \multicolumn{2}{|c|}{$\begin{array}{c}\text { Conventional } \\
\text { (Baseline) }\end{array}$} & \multicolumn{2}{|c|}{ Simple Hinged Flap } \\
\hline & & Nominal & $\begin{array}{c}\text { Range } \\
\text { (Estimation) } \\
\end{array}$ & Nominal & $\begin{array}{c}\text { Range } \\
\text { (Estimation) } \\
\end{array}$ \\
\hline \multirow{2}{*}{ Slat Deflection } & Landing & $30^{\circ}$ & $\begin{array}{c}27^{\circ} \text { to } 33^{\circ} \\
\left(3^{\circ} \text { increment }\right)\end{array}$ & $30^{\circ}$ & $\begin{array}{c}27^{\circ} \text { to } 33^{\circ} \\
\left(3^{\circ} \text { increment }\right)\end{array}$ \\
\hline & Takeoff & $22^{\circ}$ & $\begin{array}{c}19^{\circ} \text { to } 25^{\circ} \\
\left(3^{\circ} \text { increment }\right)\end{array}$ & $22^{\circ}$ & $\begin{array}{c}19^{\circ} \text { to } 25^{\circ} \\
\left(3^{\circ} \text { increment }\right)\end{array}$ \\
\hline \multirow{2}{*}{ Slat Gap } & Landing & $1.0 \% \mathrm{C}_{\mathrm{ref}}$ & 0 to $3 \% \mathrm{C}_{\text {ref }}$ & $1.0 \% \mathrm{C}_{\mathrm{ref}}$ & 0 to $3 \% \mathrm{C}_{\text {ref }}$ \\
\hline & Takeoff & $0.3 \% \mathrm{C}_{\mathrm{ref}}$ & 0 to $3 \% \mathrm{C}_{\text {ref }}$ & $0.3 \% \mathrm{C}_{\mathrm{ref}}$ & 0 to $3 \% \mathrm{C}_{\text {ref }}$ \\
\hline \multirow{2}{*}{ Slat Overhang } & Landing & $-0.8 \% \mathrm{C}_{\mathrm{ref}}$ & -1 to $2 \% \mathrm{C}_{\mathrm{ref}}$ & $-0.8 \% \mathrm{C}_{\mathrm{ref}}$ & -1 to $2 \% \mathrm{C}_{\mathrm{ref}}$ \\
\hline & Takeoff & $1.5 \% \mathrm{C}_{\mathrm{ref}}$ & -1 to $2 \% \mathrm{C}_{\text {ref }}$ & $1.5 \% \mathrm{C}_{\mathrm{ref}}$ & -1 to $2 \% \mathrm{C}_{\mathrm{ref}}$ \\
\hline \multirow[t]{2}{*}{ Flap Deflection } & Landing & $37^{\circ}$ & $\begin{array}{c}34^{\circ} \text { to } 43^{\circ} \\
\left(3^{\circ} \text { increment }\right)\end{array}$ & $50^{\circ}$ & $\begin{array}{c}40^{\circ} \text { to } 60^{\circ}\left(10^{\circ}\right. \\
\text { increment })\end{array}$ \\
\hline & Takeoff & $25^{\circ}$ & $10^{\circ}$ and $25^{\circ}$ & $25^{\circ}$ & $10^{\circ}$ and $25^{\circ}$ \\
\hline \multirow{2}{*}{ Flap Gap } & Landing & $1.25 \% \mathrm{C}_{\mathrm{ref}}$ & 0 to $1.5 \% \mathrm{C}_{\mathrm{ref}}$ & $\mathrm{N} / \mathrm{A}$ & $\mathrm{N} / \mathrm{A}$ \\
\hline & Takeoff & $0.9 \% \mathrm{C}_{\mathrm{ref}}$ & 0 to $1.5 \% \mathrm{C}_{\text {ref }}$ & $\mathrm{N} / \mathrm{A}$ & $\mathrm{N} / \mathrm{A}$ \\
\hline \multirow{2}{*}{ Flap Overhang } & Landing & $1.2 \% \mathrm{C}_{\mathrm{ref}}$ & 1 to $4 \% \mathrm{C}_{\text {ref }}$ & N/A & $\mathrm{N} / \mathrm{A}$ \\
\hline & Takeoff & $3.3 \% \mathrm{C}_{\mathrm{ref}}$ & 1 to $4 \% \mathrm{C}_{\text {ref }}$ & $\mathrm{N} / \mathrm{A}$ & $\mathrm{N} / \mathrm{A}$ \\
\hline
\end{tabular}

Note: $\mathrm{C}_{\mathrm{ref}}=$ local wing chord for the slat and outboard flap, and $\mathrm{C}_{\mathrm{ref}}=$ wing chord at the yehudi break for the inboard flap.
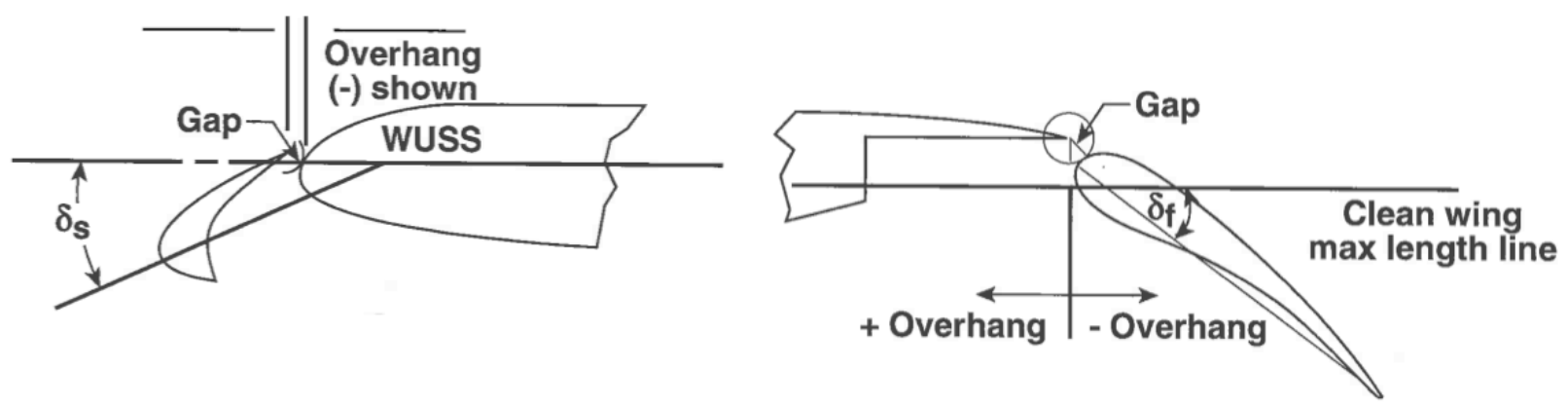

Figure 7. Gap and overhang definition for multi-element high-lift configuration. ${ }^{43}$ 
Figures 8 to 12 display some CAD images of the model. The center spar layout is shown in Fig. 8 . For illustration standardization purposes, the image of Fig. 8 is flipped from that of Fig. 6 such that the flow direction is from left to right. The spar will be hollow to allow for routing of instrumentation and AFC plumbing. The model will have the capability for testing with and without the engine nacelle. There will be a filler piece to connect the inboard and outboard slats when the engine nacelle is not installed, as shown in Fig. 9. Figures 10 and 11 show the images of the tunnel floor without any acoustic treatment for the aerodynamic testing and with the acoustic treatment for the aeroacoustic testing, respectively. Notice that the model will have a removable horizontal tail as a test option (see Fig. 10). The aeroacoustic testing requires a deeper floor due to the acoustic treatment, and thereby needs a specially made balance extension (see Fig. 11). The model will have a double-hinged mount at the model/balance interface to enable the model to be tilted to a horizontal position (in both directions) for more efficient model changes and to enhance test productivity.

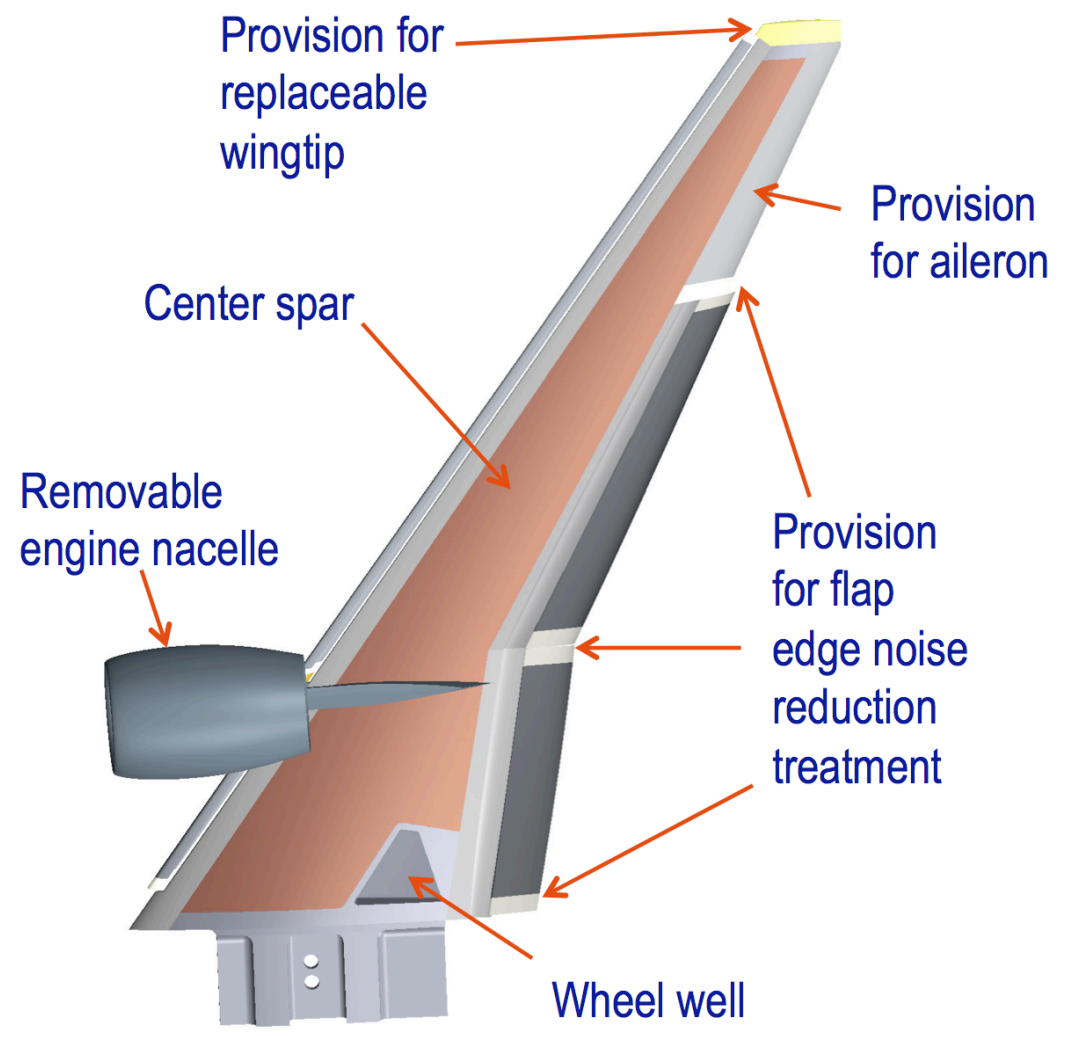

Figure 8. HL-CRM modular features.

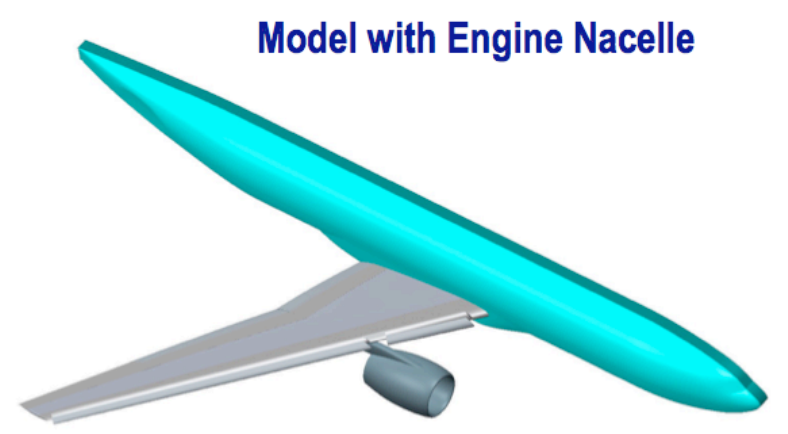

Figure 9. HL-CRM with and without engine nacelle. 


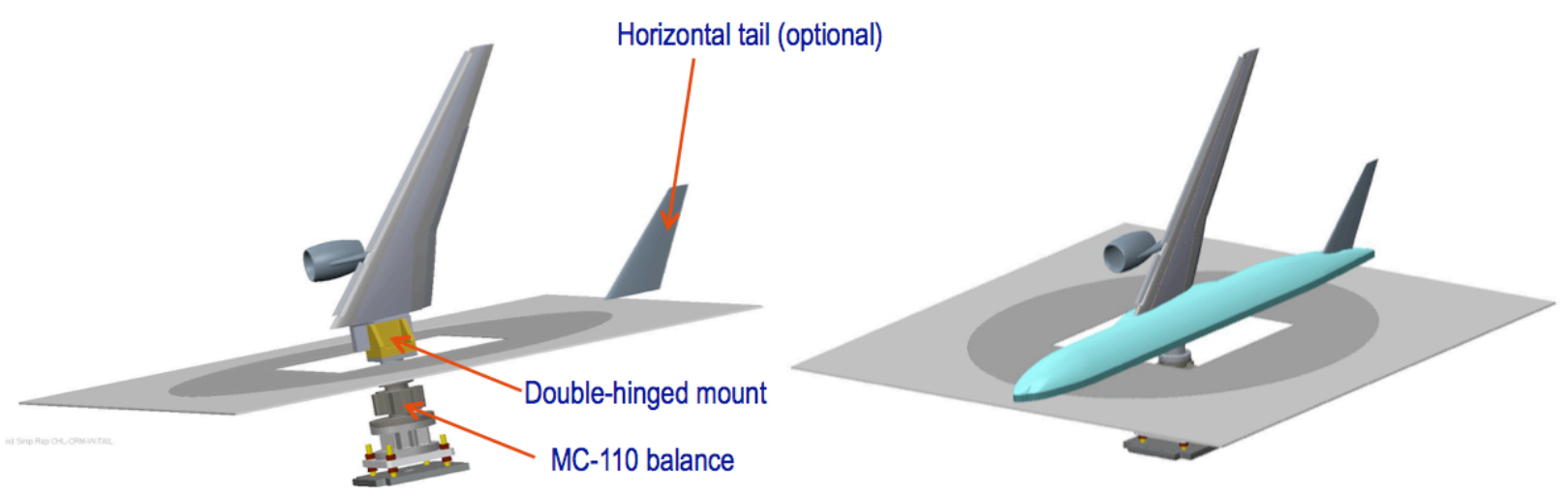

Figure 10. HL-CRM with regular (non-acoustic) flooring.

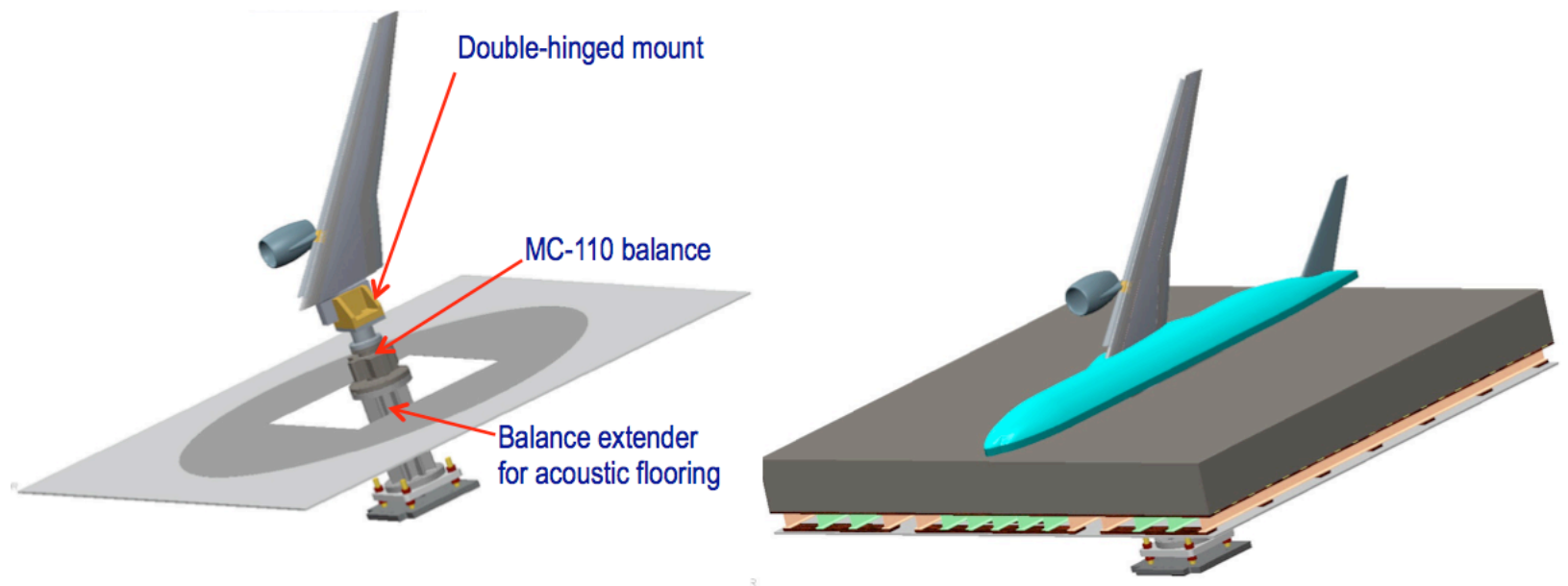

Figure 11. HL-CRM with acoustic flooring.

\section{Project Schedule}

A schedule summary of the HL-CRM project is shown in Fig. 12. The model design is ongoing, and its completion date is estimated to be March 31,2017. There is a 12-month period for model fabrication. The wind tunnel testing is scheduled to start around June 2018 and end in March 2019.

After the results for the AFC-enabled simple hinged flap high-lift test are analyzed, a decision will be made on whether to move forward with a larger scale $(\sim 30 \%)$ model wind tunnel test and/or a flight test. In addition, if the effort to develop a low pneumatic power AFC system is successful, it may enable AFC applications on advanced aircraft designs that use simple hinged flaps (e.g., Blended Wing Body) and provide (dual-use) AFC opportunities for high performance aircraft.

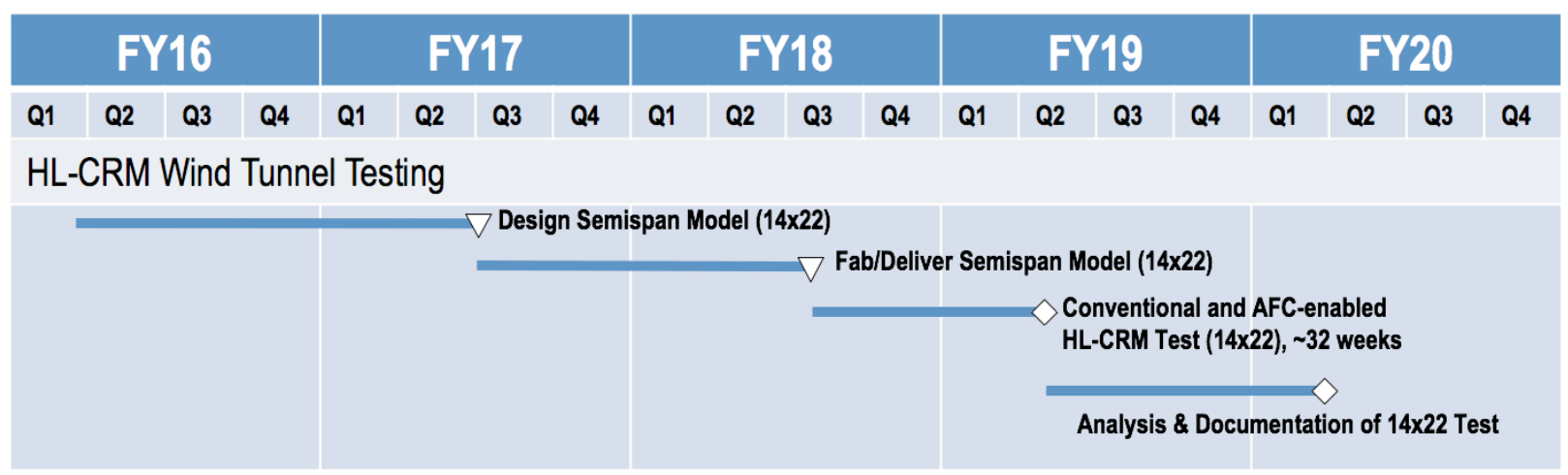

Figure 12. Timeline for the development and testing of the HL-CRM. 


\section{Test Plan}

There will be $\sim 32$ weeks of tunnel occupation time at the $14 \times 22$. Aerodynamic tests will be conducted in the first half ( $\sim 14$ weeks) with closed sidewalls, and aeroacoustic tests will be conducted in the second half ( 14 weeks) with opened sidewalls. A 4-week period is required for reconfiguring the wind tunnel from aerodynamic mode to acoustic mode. The aerodynamic testing will include a rigging study that includes adjustments to the flap/slat gap, overhang, and deflection settings in order to refine the nominal conventional (baseline) high-lift configuration. Localized AFC for L/D enhancement, AFC-enhanced simple hinged flap, and nominal conventional configuration with SCF and SGF devices will be tested in the aerodynamic portion. In addition to examining the effectiveness of various noise reduction devices, the aeroacoustic testing will also include acoustic measurements of the nominal conventional configuration and some selected AFC-enabled configurations. Table 4 illustrates the test plan for the HL-CRM test in the $14 \times 22$.

Table 4. Test plan for HL-CRM at the $14 \times 22$.

\begin{tabular}{|c|c|c|c|c|}
\hline & Test Description & $\begin{array}{c}\text { Model } \\
\text { Configuration }\end{array}$ & Measurement Techniques & $\begin{array}{l}\text { Estimated } \\
\text { Duration }\end{array}$ \\
\hline \multirow{4}{*}{$\begin{array}{l}\text { Aerodynamic Testing } \\
\text { (Closed sidewall) }\end{array}$} & $\begin{array}{l}\text { Rigging study for } \\
\text { baseline conventional } \\
\text { HL-CRM }\end{array}$ & $\begin{array}{l}\text { Takeoff and } \\
\text { landing }\end{array}$ & \multirow{4}{*}{$\begin{array}{l}\text { Balance, surface pressures } \\
\text { (both steady and unsteady), } \\
\text { tufts, model deflection } \\
\text { using videogrammetry, } \\
\text { structure vibration using } \\
\text { laser vibrometer, flow } \\
\text { visualization using tufts } \\
\text { and IR cameras, and } \\
\text { optional PIV (schedule and } \\
\text { resource allow) }\end{array}$} & 4 weeks \\
\hline & $\begin{array}{l}\text { Localized AFC for } \\
\text { L/D enhancement }\end{array}$ & Takeoff & & 2 weeks \\
\hline & $\begin{array}{l}\text { AFC-enhanced simple } \\
\text { hinged flap with } \\
\text { conventional slat }\end{array}$ & Mostly landing & & 6 weeks \\
\hline & $\begin{array}{l}\text { Conventional HL- } \\
\text { CRM with SCF and } \\
\text { SGF devices for slat } \\
\text { gap noise reduction }\end{array}$ & $\begin{array}{l}\text { Takeoff and } \\
\text { landing }\end{array}$ & & 2 weeks \\
\hline \multicolumn{4}{|c|}{$\begin{array}{l}\text { Wind tunnel test section reconfigured from aerodynamic mode to aeroacoustic mode } \\
\text { (from closed sidewalls to opened sidewalls) }\end{array}$} & 4 weeks \\
\hline \multirow{3}{*}{$\begin{array}{l}\text { Aeroacoustic Testing } \\
\text { (Opened Sidewall) }\end{array}$} & $\begin{array}{l}\text { Baseline conventional } \\
\text { HL-CRM (nominal } \\
\text { configuration) }\end{array}$ & $\begin{array}{l}\text { Takeoff and } \\
\text { landing }\end{array}$ & \multirow{3}{*}{$\begin{array}{l}\text { Acoustic array, force } \\
\text { balance, surface pressures } \\
\text { (both steady and unsteady), } \\
\text { tufts, model deflection } \\
\text { using videogrammetry, } \\
\text { structure vibration using } \\
\text { laser vibrometer, flow } \\
\text { visualization using tufts } \\
\text { and IR cameras, and } \\
\text { optional PIV (schedule and } \\
\text { resource allow) }\end{array}$} & 2 weeks \\
\hline & $\begin{array}{l}\text { Slat gap noise } \\
\text { reduction using SCF } \\
\text { and SGF, well as } \\
\text { optional flap edge } \\
\text { noise reduction } \\
\text { devices }\end{array}$ & $\begin{array}{l}\text { Takeoff and } \\
\text { landing }\end{array}$ & & 10 Weeks \\
\hline & $\begin{array}{l}\text { Selected AFC-enabled } \\
\text { simple hinged flap } \\
\text { configurations }\end{array}$ & Mostly landing & & 2 weeks \\
\hline
\end{tabular}

\section{Concluding Remarks}

This paper summarizes the current efforts to develop and design a 10\%-scaled semispan HL-CRM for testing at the NASA LaRC 14x22 during FY 2018. Both conventional and AFC-enabled high-lift configurations are being designed and are intended to be open geometries. In addition to the current research effort, the HL-CRM offers numerous opportunities for high-lift R\&D. Here are some potential uses for consideration:

1. The HL-CRM provides a generic, open geometry high-lift model for ongoing testing in the $14 \times 22$.

2. The model can be used as a common test bed for advanced AFC actuators and noise reduction concept studies. 
3. Since most of the wing components are modular, the model can be used to study wing geometry variations by replacing these modular components.

4. The HL-CRM can be used for collaboration opportunities with industry, academia, and other government agencies through cooperative agreements such as Space Act Agreements (SAA), NASA Research Announcements (NRA), Small Business Innovation Research (SBIR) projects, or Interagency Agreements (IA).

5. Because it is an "open" high-lift geometry, the HL-CRM design is an excellent candidate for CFD code validation activities such as the CFD High-Lift Prediction Workshop.

6. The model and geometry can be used for Federal Aviation Administration (FAA) related R\&D, such as icing studies.

\section{Acknowledgments}

This R\&D effort involved many people who provided valuable contributions through their detailed work and/or expert guidance. The contributors have come from within NASA and Boeing. Boeing developed the CRM high-lift geometry through a combination of internal R\&D and NASA task orders (2013-present). NASA contributions have been sponsored by the Fixed Wing (FW) Project from FY 2013-2014 and Advanced Air Transport Technology (AATT) Project from FY 2015-present. The authors would like to thank all those involved for their great support during the course of this R\&D effort. Some key personnel are as follows:

NASA Langley Research Center: Craig Hunter and Melissa Rivers (CFD); Dave Castle, Mark Cagle, Sandy Webb, and Reggie Kidd (model design); Dave Lockard, Travis Turner, Meelan Choudhari, Mehdi Khorrami, Florence Hutcheson, and Craig Streett (aeroacoustic); Norma Farr (model geometry); Dan Neuhart (model instrumentation); Bill Jones and Chris Rumsey (CFD workshop); Doug Nark and Hamilton Fernandez (aeroacoustic managers); Susan Wilz and Scott Anders (AATT managers); Rich Wahls (former FW manager).

Boeing Research \& Technology: Ed Whalen and Abe Gissen (AFC study managers).

Boeing Engineering Operations \& Technology: Arvin Shmilovich, Yoram Yadlin, Eric Dickey, and Pichuraman Sundaram (CFD); Peter Hartwich (system study manager); and Abdi Khodadoust (Boeing/NASA contract manager).

Boeing Commercial Airplanes: Doug Lacy, Paul Vijgen, and Tony Sclafani (high-lift aerodynamics).

\section{References}

${ }^{1}$ Van Dam, C. P., "The Aerodynamic Design of Multi-Element High-Lift Systems for Transport Airplanes," Progress in Aerospace Sciences, Vol. 38, 2002, pp. 101-144.

${ }^{2}$ Greenblatt, D. and Wygnanski, I. J., "The Control of Flow Separation by Periodic Excitation," Progress in Aerospace Sciences, Volume 36, Issue 7, 2000, pp 487-545.

${ }^{3}$ Cattafesta III, L. N. and Sheplak, M., "Actuators for Active Flow Control," Annual Review of Fluid Mechanics, Vol. 43, Issue 1, August 2010, pp. 247-272.

${ }^{4}$ McClean, J. D., Crouch, J. D., Stoner, R. C., Sakurai, S., Feifel, G. E., Feifel, W. M., and Rush, H. M., "Study of the Application of Separation Control by Unsteady Excitation to Civil Transport Aircraft," NASA/CR 1999209338, 1999.

${ }^{5}$ Hartwich, P. M., Shmilovich, A., Lacy, D. S., Dickey, E. D., Sclafani, A. J., Sundaram, P., and Yadlin, Y., "Refined AFC-Enabled High-Lift System Integration Study," NASA/CR 2016-219170, 2016.

${ }^{6}$ Loftin, L. K., "Quest for Performance - The Evolution of Modern Aircraft," NASA SP-468, 1985. https://www.hq.nasa.gov/pao/History/SP-468/ch10-5.htm.

${ }^{7}$ Shmilovich, A. and Yadlin, Y., "Traverse Actuation Method," AIAA Paper 2016-3309, 8th AIAA Flow Control Conference, Washington, D.C., June 13-17, 2016.

${ }^{8}$ Shmilovich, A., Yadlin, Y. and Clark, R.W., "Traversing Jet Actuator”, US Patent 8,336,828, December, 2012.

${ }^{9}$ Shmilovich, A. and Yadlin, Y., "Method and Apparatus for Supplying a Gas Jet Over an Aerodynamic Structure", US Patent 8,827,212, September, 2014

${ }^{10}$ Gregory, J. W. and Tomac, M. N., "A Review of Fluidic Oscillator Development and Application for Control," AIAA Paper 2013-2474, 43rd Fluid Dynamics Conference, San Diego, CA, June 24-27, 2016. 
${ }^{11}$ Graff, E., Seele, R., Lin, J., and Wygnanski, I., "Sweeping Jet Actuators - A New Design Tool for High Lift Generation," NATO Workshop on Innovative Control Effectors for Military Vehicles (AVT-215), Stockholm, Sweden, May 20-22, 2013.

${ }^{12}$ Seele, R., Graff, E., Gharib, M., Taubert, L., Lin, J., and Wygnanski, I., "Improving Rudder Effectiveness with Sweeping Jet Actuators," AIAA 2012-3244, 6th AIAA Flow Control Conference, New Orleans, LA, June 2528, 2012.

${ }^{13}$ Seele, R., Graff, E., Lin, J., and Wygnanski, I., "Performance Enhancement of a Vertical Tail Model with Sweeping Jet Actuators," AIAA 2013-0411, 51st AIAA Aerospace Sciences Meeting, Grapevine, Texas, January 7$10,2013$.

${ }^{14}$ Whalen, E. A., Lacy, D., Lin, J. C., Andino, M. Y., Washburn, A. E., Graff, E. C., and Wygnanski, I., "Performance Enhancement of a Full-Scale Vertical Tail Model Equipped with Active Flow Control," AIAA Paper 2015-0784, 53 $3^{\text {rd }}$ AIAA Aerospace Sciences Meeting, Kissimmee, FL, January 5-9, 2015.

${ }^{15}$ Andino, M. Y., Lin, J. C., Washburn, A. E., Whalen, E. A., Graff, E. C., and Wygnanski, I., "Flow Separation Control on a Full-Scale Vertical Tail Model using Sweeping jet Actuators," AIAA Paper 2015-0785, 53 ${ }^{\text {rd }}$ AIAA Aerospace Sciences Meeting, Kissimmee, FL, January 5-9, 2015.

${ }^{16}$ Whalen, E. A., Shmilovich, A., Spoor, M. A., Tran, J. T., Vijgen, P. M., Lin, J. C., and Andino, M. Y., "Fullscale Flight Demonstration of an Active Flow Control Enhanced Vertical Tail," AIAA Paper 2016-3927, 8th AIAA Flow Control Conference, Washington, D.C., June 13-17, 2016.

${ }^{17}$ Lin, J. C., Andino, M. Y., Alexander, M. G., Whalen, E. A., Spoor, M. A., Tran, J. T., and Wygnanski, I., “An Overview of Active Flow Control Vertical Tail Technology Development," AIAA Paper 2016-0056, 54th AIAA Aerospace Sciences Meeting, January 4-8, 2016.

${ }^{18}$ Hannon, J. A., Washburn, A. W., Jenkins, L. N., and Watson, R. D., "Trapezoidal Wing Experimental Repeatability and Velocity Profiles in the 14- by 22-Foot Subsonic Tunnel," AIAA Paper 2012-0706, 50th AIAA Aerospace Sciences Meeting, Nashville, TN, January 9-12, 2012.

${ }^{19}$ Streett, C. L., Casper, J. H., Lockard, D. P., and Khorrami, M. R., Stoker, R. W., Elkoby, R., Wenneman, W. F., and Underbrink, J. R., "Aerodynamic Noise Reduction for High-Lift Devices on a Swept Wing Model," AIAA Paper 2006-212, 44th AIAA Aerospace Sciences Meeting, Reno, NV, January 9-12, 2006.

${ }^{20}$ Horne, W. C., Burnside, N, J., Soderman, P. T., Jaeger, S. M., Reinero, B. R., James, K. D., and Arledge, T., K., "Aeroacoustic Study of a 26\%-Scale Semispan Model of a Boeing 777 Wing in the NASA Ames 40- by 80-Foot Wind Tunnel," NASA/TP-2004-212802, October 2004.

${ }^{21}$ Storms, B. L., James, K. D., Satran, D. R., Arledge, T., K., Burnside, N, J., Horne, W. C., and Driver, D. M., "Aerodynamics of a 26\%-Scale Semi-Span Model of the Boeing 777 in the NASA Ames 40- by 80-Foot Wind Tunnel," NASA/TP-2005-212829, January 2005.

${ }^{22}$ Vassberg, J. C., DeHaan, M. A., Rivers, S. M., and Wahls, R. A., "Development of a Common Research Model for Applied CFD Validation Studies," AIAA Paper 2008-6919, 26th AIAA Applied Aerodynamics Conference, Honolulu, HI, August 18-21, 2008.

${ }^{23}$ NASA Common Research Model, URL: http://commonresearchmodel.larc.nasa.gov, February 2008.

${ }^{24}$ Lacy, D. S. and Sclafani, A. J., "Development of the High Lift Common Research Model (HL-CRM): A Representative High Lift Configuration for Transonic Transports," AIAA Paper 2016-0308, 54th AIAA Aerospace Sciences Meeting, San Diego, CA, January 4-8, 2016.

${ }^{25}$ https://hiliftpw.larc.nasa.gov/Workshop3/geometries.html.

${ }^{26}$ Garner, P. L., Meredith, P. T., and Stoner, R. C., "Areas for Future CFD Development as Illustrated by Transport Aircraft Applications," AIAA Paper 91-1527-CP, AIAA 10th Computational Fluid Dynamics Conference, Honolulu, HI, June 24-27, 1991.

${ }^{27}$ DeSalvo, M., Whalen, E., and Glezer, A., "Enhancement of a High-Lift Airfoil using Low-Power Fluidic Actuators," AIAA 2010-4248, 5th AIAA Flow Control Conference, Chicago, IL, June 28 - July 1, 2010.

${ }^{28}$ DeSalvo, M., Whalen, E., and Glezer, A., "High-Lift Enhancement Using Active Flow Control," AIAA 20113355, 29th AIAA Applied Aerodynamics Conference, Honolulu, HI, June 27-30, 2011.

${ }^{29}$ Melton, L. P., Koklu, M., Andino, M., and Lin, J. C., "Sweeping Jet Optimization Studies," AIAA Paper 2016-4233, 8th AIAA Flow Control Conference, Washington, D.C., June 13-17, 2016.

${ }^{30}$ Scholten, W. D., Hartl, D. J., and Turner, T. L., "Development and Analysis-Driven Optimization of a Superelastic Slat-Cove Filler for Airframe Noise Reduction," AIAA Journal, Vol. 54, No. 3, March 2016, pp. 10741090, doi: 10.2514/1.J054011.

${ }^{31}$ Turner, T. L. and Long, D. L., "Development of a SMA-Based, Slat-Gap Filler for Airframe Noise Reduction," AIAA Paper 2015-0730, 23rd AIAA/AHS Adaptive Structures Conference, Kissimmee, FL, January 5$9,2015$. 
${ }^{32}$ Khorrami, M. R., Humphreys, W. M., Lockard, D. P., and Ravetta, P. A., "Aeroacoustic Evaluation of Flap and Landing Gear Noise Reduction Concepts," AIAA Paper 2014-2478, 20th AIAA/CEAS Aeroacoustics Conference, Atlanta, GA, June 16-20, 2014.

${ }^{33}$ Vatsa, V. N., Duda, B., Fares, E., and Lin, J. C., "Numerical Simulation of a High-Lift Configuration Embedded with High Momentum Fluidic Actuators," AIAA Paper No. 2016-3932, 8th AIAA Flow Control Conference, Washington, D.C., June 13-17, 2016.

${ }^{34}$ Fares, E., Wessels, M., Li, Y., Gopalakrishnan, P., Zhang, R., Sun, C., Gopalaswamy, N., Roberts, P., Hoch, J., and Chen, H., "Validation of a Lattice Boltzmann Approach for Transonic and Supersonic Simulations," AIAA Paper 2014-0952, 52nd AIAA Aerospace Sciences Meeting, National Harbor, MD, January 13-17, 2014.

${ }^{35}$ Anderson, W. K. and Bonhaus, D. L., "An Implicit Upwind Algorithm for Computing Turbulent Flows on Unstructured Grids," Computers and Fluids, Vol. 23, No. 1, 1994, pp. 1-22.

${ }^{36}$ Buning, P. G., Jespersen, D. C., Pulliam, T. H., Klopfer, W. M., Chan, W. M., Slotnick, J. P., Krist, S. E., and Renze, K. J., “OVERFLOW User's Manual Version 1.8m,” Tech. Rep., NASA Langley Research Center, 1999.

${ }^{37}$ Sclafani, A. J., Slotnick, J. P., Vassberg, J. C., Pulliam, T. H., Lee, H. C., "OVERFLOW Analysis of the NASA Trap Wing Model from the First High Lift Prediction Workshop," AIAA Paper 2011-0866, 49th AIAA Aerospace Sciences Meeting, Orlando, FL, January 4-7, 2011.

${ }^{38}$ Sclafani, A. J., Slotnick, J. P., Vassberg, J. C., Pulliam, T. H., "Extended OVERFLOW Analysis of the NASA Trap Wing Wind Tunnel Model," AIAA Paper 2012-2919, 6th AIAA Flow Control Conference, New Orleans, LA, June 25-28, 2012.

${ }^{39}$ Rumsey, C. L., Slotnick, J. P., Long, M., Stuever, R. A., and Wayman, T. R., "Summary of the First AIAA CFD High-Lift Prediction Workshop," Journal of Aircraft, Vol. 48, No. 6, November-December 2011.

${ }^{40}$ Rumsey, C. L. and Slotnick, J. P., "Overview and Summary of the Second AIAA High-Lift Prediction Workshop," Journal of Aircraft, Vol. 52, No. 4, July-August 2015.

${ }^{41} \mathrm{http}: / /$ www.aeronautics.nasa.gov/aavp/aetc/subsonic/14x22.html.

${ }^{42}$ Khorrami, M. R. and Neuhart, D. H., "Aeroacoustic Study of a High-Fidelity Aircraft Model: Part 2Unsteady Surface Pressures," AIAA Paper 2012-2234, 18th AIAA/CEAS Aeroacoustics Conference, Colorado Springs, CO, June 4-6, 2012.

${ }^{43}$ Lin, J. C., and Dominik, C. J., "Parametric Investigation of a High-Lift Airfoils at High Reynolds Numbers," Journal of Aircraft, Vol. 34, No. 4, July-August 1997, pp. 485-491. 